The effects of injections of normal saline into 15 rats were almost negligible and those of graded doses of pitressin into 50 rats showed a linear relationship between log? response (R) and dose (D) ranged 0.2-0.8 milliunit per ml. :

Log. $R=1.188+0.83 \mathrm{D}(\mathrm{p}<0.01)$

Assays for antidiuretic activity of the plasma of normal subjects were performed in 36 cases. The blood specimens were withdrawn from 12 normal subjects in the early morning, in the midday and in the evening, before each meal respectively. The results obtained revealed that plasma antidiuretic activity in the normal subjects was quite slight in the early morning, while significantly increased in the midday and tended to decrease in the evening.

\title{
Parathyroid Function in Hyperthyroidism
}

By

Takuo FUJITA, Jun ISHII, Kazuo SHIZUME and Akito NOGUGHI

Prof. Okinaka's Clinic, University of Tokyo School of Medicine and Noguchi Hospital, Beppu, Japan

Increased calcium and phosphorus excretion as well as decalcification of the skeletal system in hyperthyroidism is similar to hyperparathyroidism and osteitis fibrosa generalisata in some aspects. Calcium tolerance test described by Howard et al was carried out on 8 hyperthyroid and 10 normal subjects. "Parathyroid Index" was calculated from the results. Abuormal response to hypercalcemia was consistently found in hyperthyroidism. "Parathyroid Index" in hyperthyroidism was 1.16 in average, while that in euthyroid subjects was 3.05 . Serum phosphorus appeared to be slightly eleyated in hyperthyroid subjects.

Metabolic changes in hyperthyroidism and hyperparathyroidism are different in several aspects, but certain functional relationship seems to exist between thyroid and parathyroids.

\section{Urinary Content of Ketone Bodies and its Significance in the Management of Diabetes Mellitus \\ I. Urinary Excretion of Ketone Bodies and its Relation to Types and Complications in Diabetes Mellitus}

By

\section{Takeshi MORIWAKI}

From the First Department of Medicine, Osaka University Medical School

(Director : Prof. T. Yoshida)

Although it is well known that there is a tendency to ketosis in diabetes mellitus, laboratory examination of urinary ketone bodies has bren clinically used chiefly to detect manifest ketosis.

In Japan, qualitative test for ketone bodies is usually negative in diabetics except in those with acute complications and diabetic come is rarely encountered. However, late complications are frequently seen 


\title{
甲状腺機能九進時に於ける副甲状腺機能に就て
}

\author{
東京大学洲中队科 \\ 滕田 拓男, 石井滰, 鎮目 和夫 \\ 別府野口病院
}

野口秋人

甲状腺㙨能九進特には，カルシウム及び燐の排泄が増加し1,2)，又骨系統に於いて種々の程废に脱灰が起 る事が観察されている3 11). このカルシウム及び燐の排泄仙，外科的又心抗甲状腺剂に低る治療によつて正 常にもどる事が知られている2,12)。骨組織のカルシウム含量埌，甲状腺機能兄進の臨床例に於いても，甲状 腺ホルモンを与えて動物に於いても減少している(13 15).Aub 等1 症であり，甲状腺ホルモンの特殊異化作用にもとずく，骨蛋白質成分の減少によつて起るとし，甲状腺機能 六進症に於いてカルシウム，燐，窒素が何れも負性出納になつているてとをその根拠としたが，体内の物質

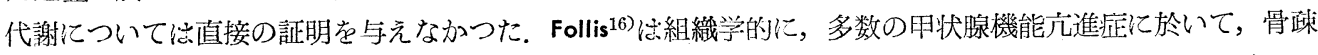

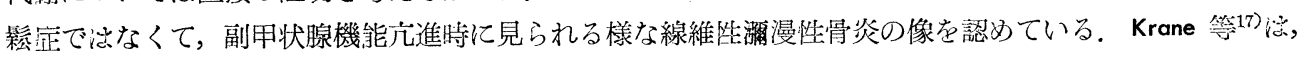

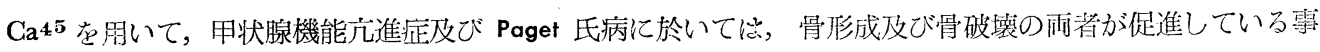

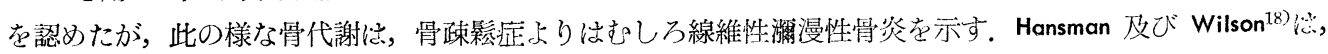
甲状腺機能九進特には副甲状腺機能充進が共存するとして，てれらの現象を説明しようとした。

副甲状腺の機能を正確に又特異的に検查すること岕困難な課題である。古典的な血中カルシリム及び燐り 值に依るきの，又尿中カルシウム排泄值に依るきの统特異性を欠き，直接副甲状腺ホルモンを体液中に証明

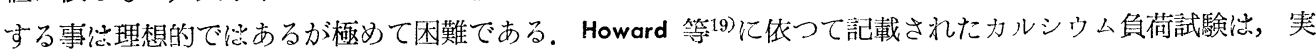
周的でかなりすぐれた副甲状腺機能険査法であるので20)，我々はてれを用いて甲状腺機能九進時の副甲状腺 機能を検查し，又著者の一人藤田がカルシウム負荷試験の結果加ら，訃算するてとを考案した副甲状腺係数 を用いて，副甲状腺機能を定量的に表すととを試みた。被検者としては，別府野口病院に於ける6 例のバセ ドり氏病患者と，5例の甲状腺機能正常者を選び，乙れを先に藤田が米国バッファロー大学慢性病研究所に 於いて行つた甲状腺機能儿進者 2 例古，正常者 5 例の検查結果と合せて比較檢討した。

\section{方法}

カルシウム負荷試験佉，被検者に 6 日間カルシウム及び燐含有量の一定な食慨を与え，且つその閆 24 侍間

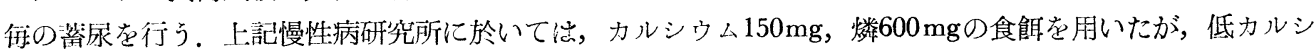
ウ人食のた少低カロリ一食となつて，中状腺機能九進患者で驻使用が困難であつたので，野口病院に於いて 出，カルシウム $600 \mathrm{mg}$ ，燐 $1000 \mathrm{mg}$ の食饂を用いた。第 5 日目に出朝食を与えず，10\%グルコン酸カルシり

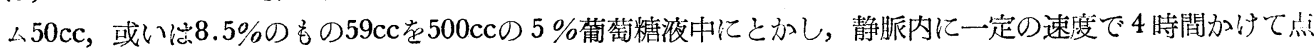
滴注入した。 点滴開始直前, 終了直後, 及び開始後 24 時間で採血し, 血清及び各 24 㭙間尿中の無機燐の值を, Fiske-Subbarow 法222 亿依つて測定した。

第 4 日目の尿中燐值を $\mathrm{UP}_{1}$, 第 5 日目のそれを $\mathrm{UP}_{2}$, 点滴開始直前の血清燐值を $\mathrm{SP}_{0}$, 点滴終了值後のそ れを $\mathrm{SP}_{4}$ ，点滴開始後24時間のそれを $\mathrm{SP}_{24}$ とすると，副甲状腺係数借

$$
\text { 副甲状狝係数 }=\frac{\frac{\mathrm{UP}_{0}}{\mathrm{SP}_{0} \times 24 \times \mathrm{GFR}}}{\frac{\mathrm{UP}_{1}}{\left\{\left(\frac{\mathrm{SP}_{0}+\mathrm{SP}_{4}}{2}\right) \times 4+\left(\frac{\mathrm{SP}_{4}+\mathrm{SP}_{24}}{2}\right) \times 20\right\} \times \mathrm{GFR}}}=\frac{\frac{\mathrm{UP}_{0}}{\mathrm{GFP}_{0}}}{\frac{\mathrm{UP}_{1}}{\mathrm{GFP}_{1}}}
$$




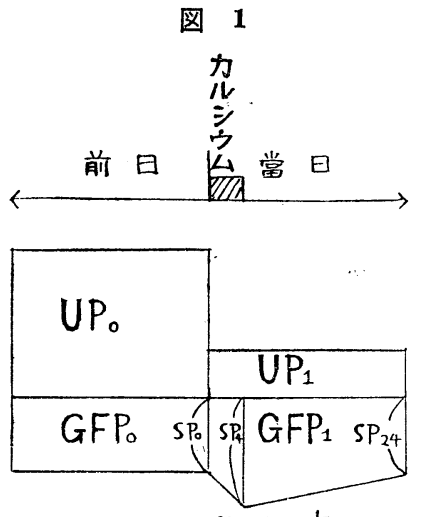

正常反應
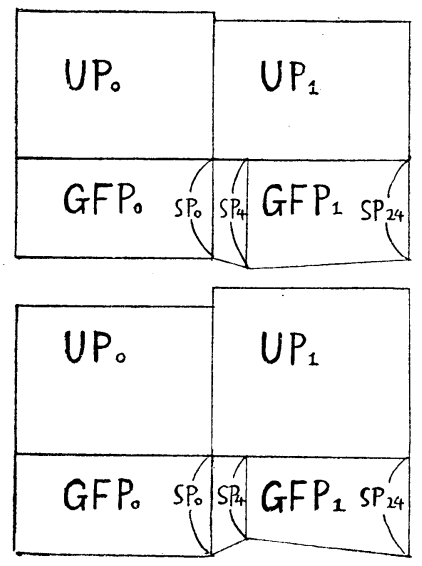

異常反應

副甲状腺係数

(Parathyroid Index)

$$
\frac{\frac{\mathrm{UP}_{0}}{\mathrm{GFP}_{0}}}{\frac{\mathrm{UP}_{1}}{\mathrm{GFP}_{1}}}
$$

$\mathrm{SP}_{0}:$ 点滴直前の低清燐

$\mathrm{SP}_{4}$ : 点滴開始後 4 時間の 而 清燐

$\mathrm{SP}_{24}$ : 点滴開始後 24 時間の 血清燐

$\mathrm{UP}_{0}$ : 前日の尿中燐

$\mathrm{UP}_{1}$ : 当日の尿中燐

$\mathrm{GFP}_{0}$ : 前日の糸球体浩過燐

GFP $P_{1}$ : 当日0糸球体滤過燐
であつて図1亿示す如くである，GFP 0 第4 日目（点滴前日）の糸 球体濾過燐量, $\mathrm{GFP}_{1}$ 第 5 日目 (点滴当日) の糸球体濾過燐量であ つて，糸球体濾過率 (GFR) 《カルシウム負荷にかかわらず一定であ るので23)，血清燐から計算したものである．副甲状腺機能が血中のカ ルシウム及び燐，乙とに前者によつて支配されているととによく知ら れて居り，高カルシウム血症によつて抑制，低カルシウム血症に依つ て促進されるのであるが，副甲状腺ホルモンの作用の一つと考えられ ている細尿管からの燐再吸収抑制に基く尿中燐排泄促進作朋虫，カル シウム負荷による离カルシウム血症の為抑制され，㣂甲状腺機能が正 常ならば，一時的副甲状腺機能低下に基く燐排泄の減少が見られる。 此の場合 $\mathrm{UP}_{1}$ が $\mathrm{UP}_{0}$ よりにるかによなり，又 $\mathrm{GFP}_{1}$ 《 $\mathrm{GFP}_{0}$ よ

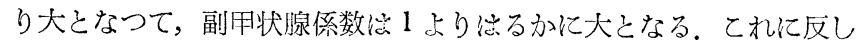
て副甲状腺機能異常時にに，副甲状腺の高カルシウ人血症に刘する反 沁減弱するので，てれらの変化心軽度であつて，副甲状腺係数住1

\begin{tabular}{|c|c|c|c|}
\hline & 正 常 & $\begin{array}{l}\text { 里 状腺 } \\
\text { 機能兄進 }\end{array}$ & $\begin{array}{l}\text { 副甲状 } \\
\text { 腺 腫 }\end{array}$ \\
\hline & 33 우 & 62 우 & 27 今 \\
\hline $\mathrm{UP}_{\mathrm{o}} \mathrm{mg} / 12 \mathrm{~h}$ & 215 & 309 & 626 \\
\hline $\mathrm{UP}_{1} \mathrm{mg} / 24 \mathrm{~h}$ & 65 & 424 & 641 \\
\hline $\mathrm{SP}_{0} \mathrm{mg} / \mathrm{dl}$ & 4.0 & 4.7 & 3.5 \\
\hline $\mathrm{SP}_{4} \mathrm{mg} / \mathrm{dl}$ & 5.3 & 4.9 & 3.7 \\
\hline $\mathrm{SP}_{24} \mathrm{mg} / \mathrm{dl}$ & 4.3 & 4.5 & 2.2 \\
\hline 副甲状腺係数 & 3.95 & 0.73 & 0.85 \\
\hline
\end{tabular}
に近くなる。その1例を表1亿示す。.

表 1 カルシウム負解試験の絬果

結 果

表 2 の示す如く，高カルシウム血症に対する反応の異常に，甲状晾 機能穴進症の殆んど全例について見られた．副甲状腺係数は，正常者 で统，平均3.05であるのに反し，甲状腺機能过進者に於いては，平均 1.16 であつた.

血清燐值について，正常者之甲状腺機能方進者とを比輍すると，正 常者 3.9 , 甲状腚機能立進者 4.6 であつて, 甲状腺機能充進者に於いて や〉高いととが注目される。

考按

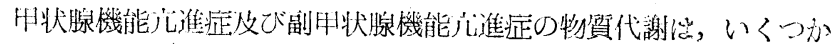
の点で異つている．即ち血清カルシウム及び燐炕，甲状腺機能过進症

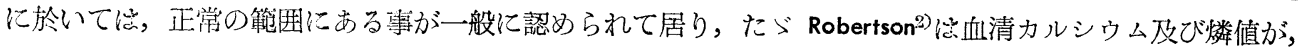

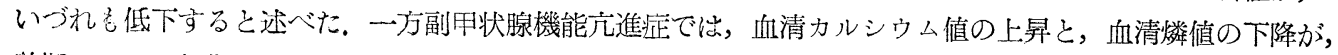

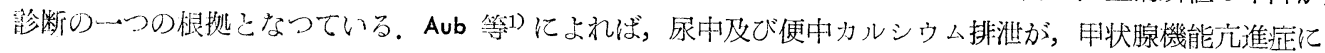

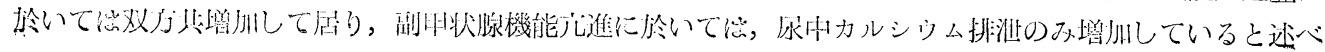


表 2 カルシウム負荇試験の結果

正常 例

\begin{tabular}{|c|c|c|c|c|c|c|c|c|c|}
\hline 氏 名 & 年令性 & $\mathrm{UP}_{0}$ & $\mathrm{UP}_{1}$ & $\mathrm{SP}_{\mathrm{o}}$ & $\mathrm{SP}_{4}$ & $\mathrm{SP}_{24}$ & 係 数 & BMR & $\begin{array}{c}\mathrm{I}^{\mathbf{1 3 1} 1} \\
\text { 提取率 }\end{array}$ \\
\hline 企○初○ & 25 우 & 538 & 264 & 3.5 & 3.4 & 4.7 & 2.30 & +3.8 & 5 \\
\hline 緒○ッ○ & 21 우 & 411 & 370 & 4.3 & 4.8 & 4.3 & 1.18 & & \\
\hline 山○良○ & 19우 & 459 & 112 & 4.0 & 4.4 & 4.8 & 4.64 & -2.5 & \\
\hline$山 \bigcirc$ 数 $\bigcirc$ & 17 우 & 497 & 275 & 3.7 & 4.1 & 4.7 & 2.11 & -4.6 & 5 \\
\hline 小○チ○ & 26 우 & 506 & 289 & 3.3 & 3.9 & 3.7 & 2.00 & +2.7 & 16 \\
\hline$\Delta$ E.H. & 20 우 & 568 & 190 & 3.8 & 4.2 & 4.3 & 3.31 & & \\
\hline D.H. & 33 우 & 215 & 65 & 4.0 & 5.3 & 4.3 & 3.95 & & \\
\hline$\triangle$ T.F. & $25 \hat{\jmath}$ & 760 & 340 & 3.7 & 4.1 & 4.4 & 2.53 & & \\
\hline A.B. & 45 우 & 589 & 106 & 4.2 & 4.5 & 4.6 & 5.98 & & \\
\hline А E.B. & 49 우 & 662 & 286 & 4.0 & 4.6 & 4.2 & 2.54 & & \\
\hline 均 & & & & 3.9 & & & 3.05 & & \\
\hline
\end{tabular}

师腺機能九進例

\begin{tabular}{|c|c|c|c|c|c|c|c|c|c|}
\hline 氏 名 & 年命性 & $\mathrm{UP}_{0}$ & $\mathrm{UP}_{1}$ & $\mathrm{SP}_{0}$ & $\mathrm{SP}_{4}$ & $\mathrm{SP}_{24}$ & 係 数 & BMR & 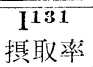 \\
\hline 北 $\bigcirc$ 喜 & 27 우 & 828 & 728 & 4.7 & 5.3 & 4.1 & 1.15 & +58.6 & 52.5 \\
\hline 永 $\bigcirc$ 正 & $36 \hat{\jmath}$ & 540 & 756 & 4.1 & 4.8 & 5.3 & 0.86 & +43.5 & 41.8 \\
\hline 片○ヶ & 27 우 & 516 & 396 & 5.3 & 5.2 & 4.0 & 1.16 & +51.5 & 21.2 \\
\hline 山○チ○ & 19 우 & 440 & 392 & 4.3 & 5.7 & 5.4 & 1.42 & +47.5 & 62.0 \\
\hline 渡 $\bigcirc$ 美 $\bigcirc$ & 20 우 & 626 & 466 & 4.3 & 5.0 & 4.8 & 1.52 & +44.5 & 33.1 \\
\hline 如 $\bigcirc$ 房 & 16 우 & 464 & 378 & 4.9 & 6.0 & 3.7 & 1.24 & +39.3 & 69.5 \\
\hline$\Delta \mathrm{E} . \mathrm{J}$. & 41 우 & 695 & 740 & 4.4 & 6.8 & 4.3 & 1.19 & +60.0 & \\
\hline$\Delta$ R.H. & 62 우 & 309 & 424 & 4.7 & 4.9 & 4.5 & 0.73 & +24.0 & 39.0 \\
\hline 均 & & & & 4.6 & & & 1.16 & & \\
\hline
\end{tabular}

望 1) A印は慢性病研究所に於ける症例である

2) $\mathrm{UP}_{0}$ : 圾験第 4 日（点㵜前日）24時間尿中燐 $\mathrm{mg}$

$\mathrm{UP}_{1}$ ： " 5 " (点滴当日)

$\mathrm{SP}_{0}$ : 点涌開始值前血清燐 $\mathrm{mg} / \mathrm{dl}$

$\mathrm{SP}_{4}$ : 点滴終了直後血清燐 $\mathrm{mg} / \mathrm{dl}$

$\mathrm{SP}_{\mathbf{2 4}}$ : 点滴開始後 24 時間血清燐 $\mathrm{mg} / \mathrm{dl}$

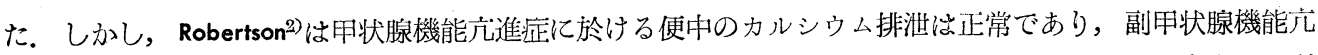

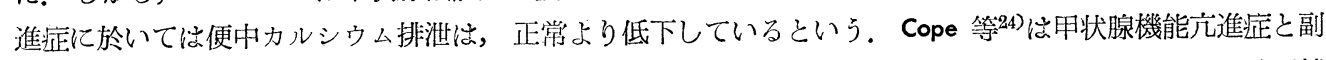
甲状腺機能低下症の共存する例を報告し，甲状腺機能充進時には，常に副甲状腺を介してカルシウム及び燐 の排泄が増加するので岕ないととを示した。 又 Aub 等25)及び Cope 等 ${ }^{24)}$ は甲状腺ホルモンが手術後の副甲 状腺機能低下症に有效である事を示し，二腺間の機能的関係を明汃に示した。 Engfeldt 等26) 住ラッテでTSH 及び thyroxine を周いて, 副甲状腺の增大及び細胞学的に機能立進の像を作り, 又此の時, 血清燐值の上开

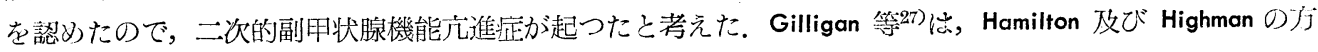
法288亿依り，甲状腺機能充進症患者の血液を鬼飞注射して，副甲状腺示ルモン様作用として，鬼の血清カル シリ人上昇について観祭したが，甲状腺機能充進症に於いて绝正常より高い值を得た。以上の如く甲状腺機 能充進と副甲状腺機能充進の間に虻，勿論相違绾あるが，雨腺間に密接な機能的関係の存在する事も，亦否 
定出来ない，我々の検查成績纪，甲状腺機能克進時に心，副甲状腺機能に異常があるととを示すものである。 その機瑇については志だ明らかでないが，Engfeldt 等20)の観察したラッテの笑駼的甲状腺機能九進症に於け

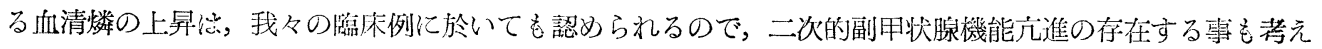

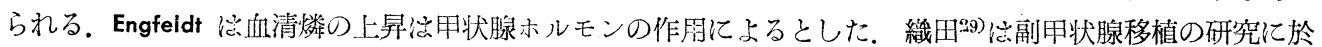
いて，甲状腺を切除して扔くと，移植した副甲状腺の発育及び機能維持の覀いてとを認めているが，甲状腺 ホルモンの副甲状腺に及! 导す保護乃至刺激作用を示すものとして注目される。他方甲状腺機能を九進せしぬ る如き因子が同時に副甲状腺に働いているかる知れず，此の意味で，下垂体又住自律神経の関与を否定出来

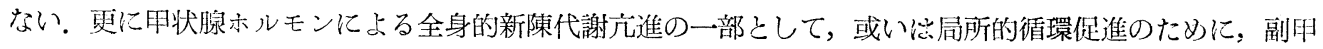

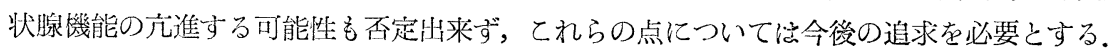

総 括

カルシウム顀荷陚験とそれに基く副甲状腺係数計算を，8例の甲状腺機能充進者と，10例の正常者につい て行い，甲状腺機能艺准者では，副甲状腺の高カルシウム血症に対する反応性に異常があり，副甲状腺係数

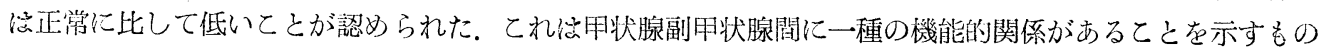
と考えられる。

恩師沖中教授, 新潟大学西川教授の御校閲を感謝します。.

\section{文献}

1) Aub, J. C., W. Baver, C. Heath, \& M. Ropes : J. Clin. Invest. $7: 97,1929$. Laucet $1: 672,1942 . \quad 3)$ Köppen : Neurologisch. Zentralblatt $11: 219,1892$.

2) Robertson, J. D. : \& A.B. Moore : Medical Clinics Nortn America 12 : 1511, 1929.

5) Hunter, D. : Lancet $1: 947,1930$ 6) Plummer, W.A. : Proc. staff. Meet. Mayo Glinic $3: 119,1928$.

7) Askanazy, M. \& E. Rutishauser : Virchows Archiv $291: 653,1933$. 8) Martos, J. : Beitr. path. Anat. $100: 293,1938$ 9) Brunner, W. : Deutsch. Z. Chir. 254 : 133, 1940. 10) Nielsen, H. : Acta medica scand. suppl. $266: 783$, 1952. 11) Golden, R. \& H. Abbott : Amer. J. Roentgenol. $30: 641,1933$. 12) Green, J. \& A. Lyall : Lancet $1: 828,1951$. 13) Drill, V.A. : Proc. Soc. Exp. Biol. \& Med $48: 448,1941$. Smith, E. E. \& F. C. McLean : Endocrinology $23: 546,1938$.

15）小川蕃：日本外科学会雑誌，26回， 32 , 大正14年. 16) Follis, R.H. : Bull. Johns Hopkins Hosp. 92 : 405, 1953.

17) Krane, S.M., G.L. Brownell, J.B. Stanbury, \& H. Corrigan : J. Clin. Invest $35: 874,1956$. 18) Hansman, F.S. \& F.H. Wilson : Med. J. Australia $1: 37,1934$. 19) Howard, J. E., T. R. Hopkins, \& T. B. Connnor : J. Clin. Endocrinol \& Metab. $13: 1,1953$. 20) Chambers, E.L. Jr., G.S. Gordan, L. Goldman, \& E.C. Reifenstein, Jr. : J. Glin. Endocrinol \& Metab. $16: 1507,1956$. 22) Fiske, C. H. \& Y. Subbarow : J. Biol. Chem. $66: 375,1925$. 21) 藤田拓男 : Metabolism $5: 87,1956$. J. Glin. Invest. $36: 573,1957$. 24) Cope, O., \& G. A. Donaldson : J. Glin. Invest. $16: 329,1937$ 25) Aub, J.C. F. Albright, W. Baver, \& E. Rossmeisl : J. Glin. Invest. $11: 211,1932$. \& S.O. Hiiertquist : Acta endocrinol. $15: 109$, [954. 27) Gilligan, D.R., S. L. Gargill, \& M.C. Volk : Proc. Soc. Exp. Biol. \& Med. 35 : 89, 1936. 205,1932 . 29) 織田元一郎：日本外科学会雑誌，41回，1步，127，㫿利15年. 